\title{
Composite micronutrient nanoparticles and salts decrease drought stress in soybean
}

\author{
Christian O. Dimkpa ${ }^{1} \cdot$ Prem S. Bindraban $^{1} \cdot$ Job Fugice $^{2}$. \\ Sampson Agyin-Birikorang ${ }^{2}$ - Upendra Singh ${ }^{2}$ - Deborah Hellums ${ }^{2}$
}

Accepted: 8 December 2016/Published online: 22 January 2017

(C) INRA and Springer-Verlag France 2017

\begin{abstract}
Drought decreases crop productivity, with economic consequences for farmers. For soybean, drought particularly affects the reproductive phase. There is therefore a need for strategies that minimize drought effects, such as agronomic fortification with micronutrients. Here, we evaluated the mitigation of drought stress in soybean using composite formulations of three micronutrient nanoparticles, $\mathrm{ZnO}, \mathrm{B}_{2} \mathrm{O}_{3}$, and $\mathrm{CuO}$, and their salts: $\mathrm{ZnSO}_{4} \cdot 7 \mathrm{H}_{2} \mathrm{O}, \mathrm{H}_{3} \mathrm{BO}_{3}$, and $\mathrm{CuSO}_{4}$. $5 \mathrm{H}_{2} \mathrm{O}$, in a greenhouse. The micronutrients were soil or foliar applied 3 weeks after seed germination. Drought was imposed at $50 \%$ field moisture capacity. We measured parameters related to growth, yield, and nutrient uptake dynamics during 19 weeks. Results show that drought decreased soybean shoot growth by $27 \%$ and grain yield by $54 \%$. Application of salt formulations to soil was more effective than foliar application, in mitigating drought stress. For foliar application, the effects of nanoparticles and salts were similar. On average, the formulations reduced drought effects by increasing shoot growth by $33 \%$ and grain yield by $36 \%$. On average, the formulations increased shoot $\mathrm{N}$ by $28 \%, \mathrm{~K}$ by $19 \%$, Zn by $1080 \%$, B by $74 \%$, and $\mathrm{Cu}$ by $954 \%$. Likewise, the formulations, on average, increased grain $\mathrm{N}$ by $35 \%, \mathrm{~K}$ by $32 \%, \mathrm{Zn}$ by $68 \%$, B by $56 \%$, and $\mathrm{Cu}$ by $13 \%$. In contrast, drought did not alter shoot $\mathrm{P}$, but the formulations, on average, reduced shoot $\mathrm{P}$ by $33 \%$. Whereas micronutrient salts are known to reduce drought effects in plants, our findings demonstrate for the first time a
\end{abstract}

Christian O. Dimkpa

cdimkpa@ifdc.org

1 Virtual Fertilizer Research Center (VFRC), 1901 Pennsylvania Avenue, Washington, DC 20006, USA

2 International Fertilizer Development Center (IFDC), Muscle Shoals, AL 35662, USA novel use of micronutrient nanoparticles to boost crop performance and $\mathrm{N}$ and $\mathrm{P}$ uptake under drought stress.

Keywords Agronomic fortification $\cdot$ Climate-smart fertilization · Drought $\cdot$ Micnobits $\cdot$ Micronutrients $\cdot$ NPK . Nanofertilizers $\cdot$ Nutrient uptake dynamics

\section{Introduction}

Crop production is affected by multiple environmental stresses, including disease and pest aggression, low soil fertility, and inadequate water supply. Insufficient water supply and/or poorly distributed rainfall, collectively described here as drought, affects both vegetative and reproductive development of crops. Thus, in economic terms, yield loss from drought has severe ramifications not only for farming households, but also for entire agrarian communities, whole regions, and even nations. For example, according to the US Natural Resources Defense Council (NRDC), 80\% of all farm losses in the USA in 2012 were due to drought, heat, and wind, for which $\$ 17.3$ billion was paid by insurance companies to farmers to cover losses (https://www.nrdc.org/media/2013 /130827). Still, beside food and economic losses, the ecological implications of drought include degradation of soil, loss of soil microflora, and loss of wildlife and habitats. For soybean, drought impact at field scale is demonstrated in Fig. 1 (upper panel), where one of the early vegetative symptoms, namely leaf wilting, is evident. However, in addition to vegetative growth retardation, soybean is very sensitive to drought during the reproductive growth phase, whereby increased flower abortion, reduced pod number, reduced seed per pod, and small seed size are the eventual outcomes (see for, e.g., Pardo et al. 2015). Some of these impacts are exemplified in Fig. 1 (lower panel), where 

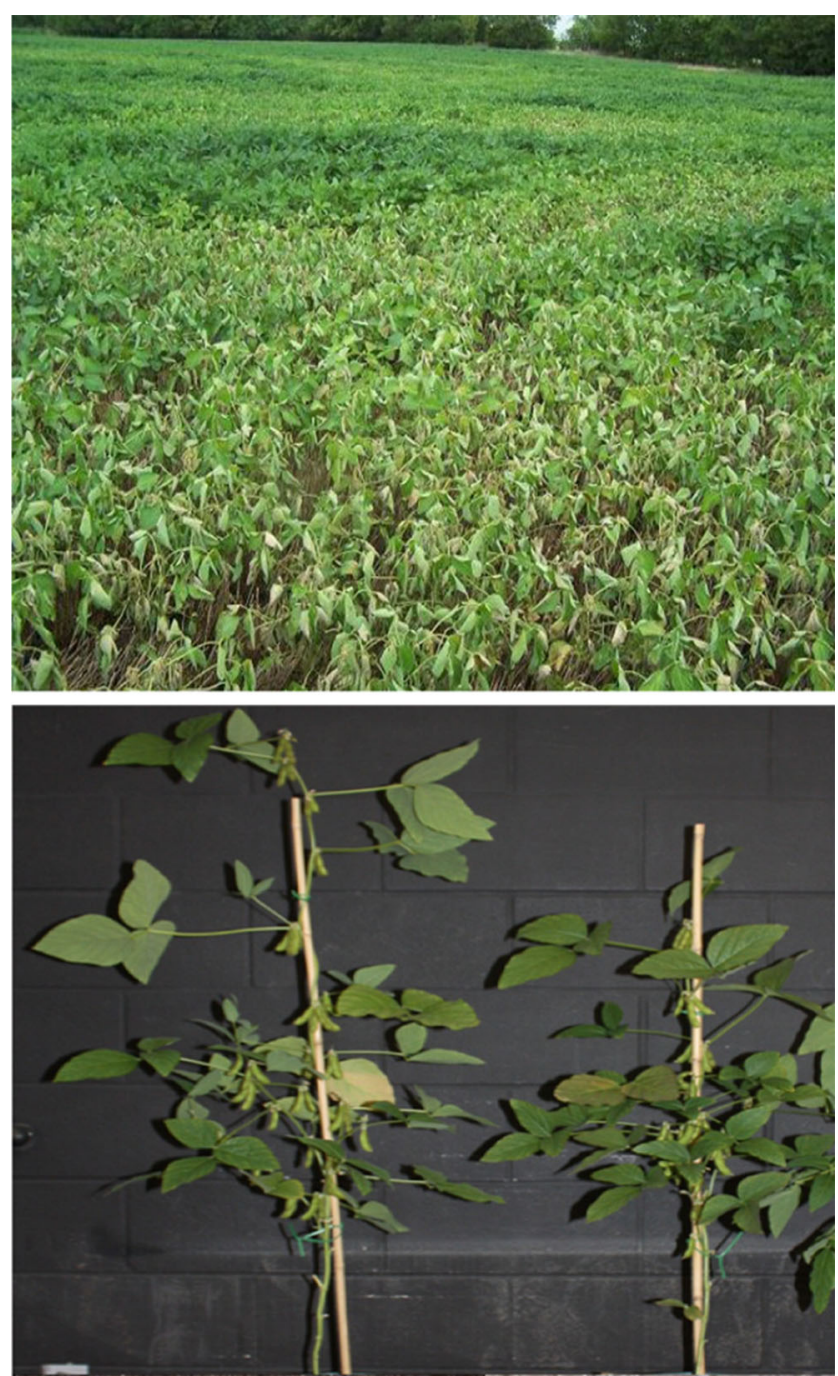

Fig. 1 Upper panel: Wilting soybean plants in a field affected by severe water scarcity. Image courtesy of S. Duncan, D. Shoup, and K. Roozeboom, Kansas State University, with permission. Lower panel: Individual soybean plants under optimal (left) and suboptimal (right) soil moisture regimes. By visual observation, plants under no drought stress are taller, with more pod formation, than drought-stressed plants, implying that their biomass is also greater (image from this study; see Sect. 3 for more details)

reduction in growth and pod formation could be observed at the individual plant level.

Healthy crops supplied with adequate nutrition may be able to tolerate drought stress, in part due to the physiological roles of certain micronutrients in water absorption by plants (Osakabe et al. 2014). Also, there is a strong relationship between soil moisture and nutrients that influence crop performance. In dry soils with low soil solution phase, nutrient mobility and plant uptake are impeded (Al-Kaisi et al. 2013). Accordingly, the uptake efficiencies of nitrogen $(\mathrm{N})$, phosphorus $(\mathrm{P})$, and potassium $(\mathrm{K})$, already low $(10-50 \%)$ (Baligar et al. 2001) under normal soil moisture regimes, can be worsened by drought (Al-Kaisi et al. 2013). This further depresses fertilizer efficiency and limits crop yield increase and, potentially, crop produce nutritional quality, leading to a rise in production cost and investment risks for farmers. In addition, undesirable environmental impacts such as greenhouse gas (GHG) emissions (mainly $\mathrm{N}$ ) and eutrophication of water bodies (both $\mathrm{N}$ and $\mathrm{P}$ ) are heightened when uptake of these nutrients by plants is inefficient.

Recently, we reviewed the role of micronutrients in plants, demonstrating that they confer multiple benefits, including stimulating growth and yield, enhancing produce nutritional quality, boosting resistance or tolerance to pests and diseases, and mitigating drought impacts (Dimkpa and Bindraban 2016). Among the micronutrients, the roles of zinc $(\mathrm{Zn})$, copper $(\mathrm{Cu})$, and boron (B) in modulating crop responses to drought stress are notable. $\mathrm{Zn}$ activates several enzymes that regulate plant response to water stress. Also, as a structural constituent, $\mathrm{Zn}$ is involved in the maintenance of the integrity of biological membranes, which is especially critical for water absorption and utilization under drought stress (reviewed in Osakabe et al. 2014). These molecular-level effects of $Z n$ have translated into agronomic benefits as, for instance, reported for wheat under drought stress (Bagci et al. 2007). Similarly, both $\mathrm{Cu}$ and $\mathrm{B}$ are involved in cell wall strengthening and functioning. $\mathrm{Cu}$ is specifically required for the synthesis of lignin needed for cell wall strengthening (Yruela 2009), while B plays a role in the structural integrity of the cytoskeleton (Miwa and Fujiwara 2010). These roles bring $\mathrm{Cu}$ and $\mathrm{B}$ into play for the plant in water-deficit situations. Taken together, therefore, $\mathrm{Zn}, \mathrm{B}$, and $\mathrm{Cu}$ have ramifications for the survival of plants under droughtinduced wilting. Hence, the assumption in the current study that a composite of these micronutrients could be applied in climate-smart fertilization strategies for facilitating crop production in drought-prone agroecosystems is logical.

Furthermore, although the role of individual micronutrients in modulating plant uptake of NPK under non-drought condition has been noted (see, for example, Barik and Chandel 2006; Manzoor et al. 2014), it is important to investigate whether a combination of differently packaged and delivered micronutrients can influence plant use of NPK in fertilizers, given the effects of dry soil in nutrient availability from soil, the fact that multiple micronutrient deficiencies are common in many drought-prone farming systems (Monreal et al. 2016), and the scarcity of literature on micronutrient-induced plant uptake of NPK in drought systems. Therefore, the present study was conducted to evaluate the impact of micronutrients in modulating drought stress and NPK uptake in soybean using a combination of $\mathrm{Zn}, \mathrm{B}$, and $\mathrm{Cu}$, based on their specific functions in plant-water relations. To this end, commercially available oxides or salts of these nutrients were reformulated into composite products and delivered to soybean as soil or foliar treatments, followed by imposition of drought stress. These treatments enabled the evaluation of the effectiveness of micronutrients in provoking crop responses under drought. 


\section{Materials and methods}

\subsection{Soil preparation}

A sandy loam soil, "Brownfield," was used in the pot growth experiment conducted at the International Fertilizer Development Center's (IFDC) greenhouse in Muscle Shoals, Alabama. The $\mathrm{pH}$ of the experimental soil was 6.87 . The essential nutrient analysis of the soil shows different levels $(\mathrm{mg} / \mathrm{kg}$ soil) of these nutrients: on average, $\mathrm{N}(4.0), \mathrm{P}(2.05)$, $\mathrm{K}$ (246.0), Mg (149.5), Ca (1174.0), S (2.68), Zn (0.1), Fe (3.8), $\mathrm{Mn}(6.4), \mathrm{B}(0.5)$, and $\mathrm{Cu}(0.4)$, while Mo was below detection limit. Thus, among the nutrients in the test formulations, namely $\mathrm{Zn}, \mathrm{B}$, and $\mathrm{Cu}$, the soil was severely deficient in $\mathrm{Zn}$ and borderline deficient in B. Pots were loaded with $10 \mathrm{~kg}$ of this soil, and basal NPK at the rate of 10:100:275 (mg/kg soil) ( $\approx$ NPK $20: 200: 550 \mathrm{~kg} / \mathrm{ha}$ ) was mixed into the soil for all treatments. The sources of NPK were ammonium nitrate, monocalcium phosphate, and sulfate of potash, respectively. Thus, by using these sources of $\mathrm{P}$ and $\mathrm{K}, \mathrm{Ca}(5.8 \mathrm{mg} / \mathrm{kg}$; $\approx 11.6 \mathrm{~kg} / \mathrm{ha})$ and $\mathrm{S}(5.4 \mathrm{mg} / \mathrm{kg} ; \approx 10.8 \mathrm{~kg} / \mathrm{ha})$, respectively, also have been added into the soil.

\subsection{Experimental setup}

The treatments administered for this study included two water regimes (non-drought [80\% field moisture capacity (FMC)] and drought [50\% FMC]) and five micronutrient fertilizer treatments: salt (non-drought), control (no salt, under drought), salt (soil applied, under drought), salt (foliar applied, under drought), and nanoparticles (Micnobits; foliar applied, under drought). A combination of $\mathrm{Zn}, \mathrm{B}$, and $\mathrm{Cu}$ was used in the study as the micronutrient fertilizer treatment formulation, applied in soil or foliar. To this end, nanopowders of zinc oxide $(\mathrm{ZnO})$, copper oxide $(\mathrm{CuO})$ (Sigma-Aldrich, St. Louis, $\mathrm{MO}$ ), and boron oxide $\left(\mathrm{B}_{2} \mathrm{O}_{3}\right)$ (American Element, Los Angeles, CA) were used. The powders were described by the manufacturers as having particle sizes of $<100,<50$, and $<100 \mathrm{~nm}$, respectively, in agreement with the conventional definition of nanoscale materials, and all had a reported purity of $99 \%$. Immediately prior to application, individual powders were weighed out based on the content of the respective mineral element ( $\mathrm{Zn}, \mathrm{Cu}$, and $\mathrm{B})$, physically mixed to achieve uniformity, and then suspended in water to create a single stock solution at $1.77,0.80$, and $0.92 \mathrm{~g} / \mathrm{l}$ of $\mathrm{ZnO}, \mathrm{CuO}$, and $\mathrm{B}_{2} \mathrm{O}_{3}$, respectively. The product was previously termed "Micnobits" (mixture of mineral nutrient particles of nano and micron/submicron sizes; Dimkpa and Bindraban 2016), a term depicting prior findings that upon interaction with environmental matrices, including water, metal oxide nanoparticles tend to form aggregates that range from nano to micron sizes (see for, e.g., Dimkpa et al. 2013). Similarly, salts of Zn (from $\mathrm{ZnSO}_{4} \cdot 7 \mathrm{H}_{2} \mathrm{O}$ ), $\mathrm{Cu}$ (from $\mathrm{CuSO}_{4} \cdot 5 \mathrm{H}_{2} \mathrm{O}$ ), and $\mathrm{B}$ (from
$\mathrm{H}_{3} \mathrm{BO}_{3}$ ) of same amount each of $\mathrm{Zn}, \mathrm{Cu}$, and $\mathrm{B}$ as in the micnobit formulation were combined to generate the "salt" treatment, in a single stock solution composed of $6.25,2.5$, and $1.63 \mathrm{~g} / 1$ of $\mathrm{ZnSO}_{4} \cdot 7 \mathrm{H}_{2} \mathrm{O}, \mathrm{CuSO}_{4} \cdot 5 \mathrm{H}_{2} \mathrm{O}$, and $\mathrm{H}_{3} \mathrm{BO}_{3}$, respectively. The micronutrient rates in the nanoparticle and salt formulations, amounting to $2.8 \mathrm{mg} \mathrm{Zn} / \mathrm{kg}, 0.6 \mathrm{mg} \mathrm{B} / \mathrm{kg}$, and $1.3 \mathrm{mg} \mathrm{Cu} / \mathrm{kg}$, were individually within the lower range of levels 2-30 mg Zn/kg, 0.28-2.8 mg B/kg, and 1.25-100 mg $\mathrm{Cu} / \mathrm{kg}$, reported to enhance soybean productivity in studies devoid of drought stress (Reinbott and Blevins 1995; Heitholt et al. 2002; Han et al. 2011). A drop of commercial detergent was added to each stock solution, to act as surfactant to reduce the surface tension of the products and therefore aid their penetration into the leaves.

\subsection{Plant material and growth condition}

Treatments were randomly assigned using a block design comprising of three replicated plants for three different harvest periods ( 15 plants per harvest; 45 plants in total). The harvest periods included one at the vegetative phase (harvest 1 (H1)) and two at the reproductive phase (harvests $2(\mathrm{H} 2)$ and 3 (H3)). A batch of soybean seeds [Glycine max (L.) var. Stonewall; life cycle: 120-140 d] obtained from a local source in Muscle Shoals, AL, was used. The seeds were inoculated by coating with Bradyrhizobium japonicum ( $3.13 \mathrm{~g} / \mathrm{kg}$ seed) and then sown (July 9,2015) at three seeds per pot, which was later thinned down to one seedling after emergence.

Twenty-one days after seedling emergence, the composite nutrient products were applied via soil drenching (for the salts) or via foliar spray (for the salts and micnobits), with each plant receiving the $2.8 \mathrm{mg} \mathrm{Zn} / \mathrm{kg}$ soil, $1.3 \mathrm{mg} \mathrm{Cu} / \mathrm{kg}$ soil, and $0.6 \mathrm{mg}$ $\mathrm{B} / \mathrm{kg}$ soil. In contrast, the control treatment received neither soil nor foliar micronutrient application. For the foliar application, immediately prior to spraying, the concerned plants were separated according to treatments (salt vs. micnobit) and spraying was subsequently conducted in separate areas, to avoid cross contamination of the aerosols. To this end, an equal volume $(180 \mathrm{ml})$ of each product formulation was used to spray simultaneously on each nine plant sets ( 3 replicates $\times 3$ harvest times), such that each one plant in a set received an average of $20 \mathrm{ml}$ of the solution. Plants were sprayed horizontally, from the bottom, and from the top, using plastic handheld spray bottles that were continuously agitated manually to keep the particles in suspension. After spraying each group of plants, they were allowed to air-dry for $10 \mathrm{~min}$ before being returned to the experimental blocks. Only very few liquid drips from the leaves were visually observed; almost all of the spray that hit the leaves remained on them due to the added detergent that promoted stickiness.

Drought was imposed 14 days after treatment application, corresponding to 35 days after seedling emergence. A FMC of $80 \%$ was determined as the non-drought condition, while $50 \%$ 
of FMC was administered as the drought condition and maintained daily throughout the study by randomly weighing three pots from each replication a minimum of twice per day (minimum of six pots from every replication weighed everyday) and the average amount of water needed is then applied to all pots to maintain the water regime. All other standard crop greenhouse operations, including temperature and relative humidity regulations, apply.

\subsection{Data collection and analysis}

Soil-Plant Analyses Development (SPAD) readings to estimate chlorophyll content were taken using a SPAD meter (Konica Minolta). Four different readings were taken on the 19th day after seed sowing (DAS) (July 28, 2015), 32nd DAS (August 10, 2015), 46th DAS (August 24, 2015), and 56th DAS (September 3, 2015). Three destructive samplings were made during the growth period: the first at "early" growth phase (on September 8, 2015; 8 weeks after seedling emergence), the next at "mid"-growth phase (on October 6, 2015; 12 weeks after seedling emergence), and finally at physiological maturity (on November 17, 2015; 17 weeks after sowing). Prior to each harvest, shoot height, number of leaves, and the leaf area were determined. At each harvest, the fresh weight of the aboveground biomass was also determined. Subsequently, harvested shoots were washed thoroughly in water to eliminate surface-adsorbed materials as much as possible and dried at $\sim 60{ }^{\circ} \mathrm{C}$ to determine the dry matters yield, after which the samples (leaves and stems) were ground and analyzed for shoot nutrient content. Root growth was determined by measuring the length of the longest root in each plant; the roots were then dried and weighed for biomass production. At the second and final harvests, yield attributes (pod weight, grain number, and weight) and grain nutrient contents were determined. For all nutrient analysis, samples were ground, aciddigested, and subjected to standard plant tissue analytical methods: ICP-OES for $\mathrm{K}, \mathrm{Ca}, \mathrm{Mg}, \mathrm{S}, \mathrm{Zn}, \mathrm{Cu}, \mathrm{B}, \mathrm{Mn}, \mathrm{Fe}$, and $\mathrm{Mo}$ and Skalar segmented flow analyzer for $\mathrm{N}$ and $\mathrm{P}$.

A two-way analysis of variance (ANOVA; OriginPro 2016) was used to determine significant differences in crop responses to the treatments and in block effects, separately for each parameter and harvest time (where applicable). A Fisher LSD mean comparison was performed to further explore the differences with significant $(p=0.05)$ ANOVA.

\section{Results and discussion}

We describe below the effects of drought on soybean vegetative development, yield and nutrient uptake dynamics, and the benefits of improved nutrition in soybean productivity, using composites of $\mathrm{Zn}, \mathrm{B}$, and $\mathrm{Cu}$, delivered as soil or foliar treatments and as ionic (salts) or nanoparticulate (micnobits) minerals, under conditions where drought stress exerted remarkable negative effects on the plants. To the best of our knowledge, this study pioneers the use of composite oxide nanoparticles of micronutrients, namely $\mathrm{Zn}, \mathrm{Cu}$, and $\mathrm{B}$ (in comparison with their ionic equivalents) to enhance crop performance under drought. It is the first of any study to report the effect of boron oxide $\left(\mathrm{B}_{2} \mathrm{O}_{3}\right)$ nanoparticles in plants.

\subsection{Effects of micronutrient formulations on soybean chlorophyll content}

Leaf chlorophyll estimates based on SPAD measurements show that drought was significant $(p=0.05)$ in influencing chlorophyll formation in the leaves, wherein SPAD values were modified in the water-deficient control treatment compared to the non-drought treatment: $23 \pm 2 \mathrm{~b}$ vs. $25 \pm 3 \mathrm{a}$ SPAD units on day $19 ; 29 \pm 4$ b vs. $31 \pm 4$ a SPAD units on day 32 ; from $34 \pm 5$ a vs. $35 \pm 3$ a SPAD units on day 46 , and $40 \pm 4$ b vs. $42 \pm 2$ a SPAD units on day 56 (letters after values indicate statistical significance, $p=0.05$ ). As indicated by these data, chlorophyll content reductions occurred under drought over the vegetative growth sampling times, except in the case of day 46 , when no significant effect was observed between these two treatments. Subsequently, the micronutrient fertilizer treatments under drought generated a positive effect on SPAD values, although the micronutrients were not consistent to the same degree in ameliorating the reduction of chlorophyll contents caused by drought: only at day 32 was the amelioration significant $(29 \pm 4 \mathrm{c}, 32 \pm 2 \mathrm{~b}, 35 \pm 4 \mathrm{a}$, and $33 \pm 2$ ab SPAD units, for the control, salt-soil, salt-foliar, and micnobit treatments, respectively), while no clear effects of the treatments were seen on other days. An early metabolic response to drought was indicated in these SPAD readings. As a measure of leaf chlorophyll content, SPAD values provide an indication of the greenness and mineral status of plants. Heitholt et al. (2002) showed that separate $\mathrm{Zn}, \mathrm{Cu}$, and $\mathrm{Mn}$ treatments increased chlorophyll (SPAD) levels in soybean in a calcareous soil. In the current study, the micronutrient formulations did not overall mitigate the negative effect of drought on SPAD values, although at specific vegetative growth periods (day 32), SPAD values significantly higher than the control were recorded in all micronutrient treatments.

\subsection{Effects of micronutrient formulations on soybean shoot vegetative and reproductive parameters}

The effects of drought and micronutrient supplementation as soil or foliar treatments were assessed on a range of vegetative parameters in soybean, including root and shoot growth, leaf area and number, and biomass production. In the case of roots, no significant effect of drought or fertilizer treatment was noted for growth, regardless of harvest time; however, root biomass (dry weight) at $\mathrm{H} 2$ significantly $(p=0.05)$ decreased 
under drought but was restored by soil-salt, but not by saltfoliar nor micnobit treatment (data not shown). Regarding shoot development, however, by comparing the non-drought and control drought treatments, it was observed that on day 61 (H1), leaf area, leaf number, and fresh shoot biomass were consistently decreased $(p=0.05)$ by drought: respectively, $4830 \pm 705$ a vs. $3094 \pm 225$ b; $41 \pm 9$ a vs. $29 \pm 2$ b, and $149 \pm 26$ a vs. $98 \pm 4$ b. However, with the micronutrient fertilizer treatments under drought, these shoot growth indices were all restored to the non-drought values. For leaf area, the values compared to $3094 \pm 225 \mathrm{~b}$ (control) were $4322 \pm 511 \mathrm{a}$, $4119 \pm 344 \mathrm{a}$, and $4123 \pm 483 \mathrm{a}$, for the salt-soil, salt-foliar, and micnobit treatments, respectively. For leaf number, the values compared to $29 \pm 2 \mathrm{~b}$ (control) were $39 \pm 6$ a, $34 \pm 3$ $\mathrm{ab}$, and $39 \pm 6 \mathrm{a}$, for the salt-soil, salt-foliar, and micnobit treatments, respectively, and for fresh shoot biomass $133 \pm 13 \mathrm{a}, 125 \pm 11 \mathrm{ab}$, and $124 \pm 4 \mathrm{ab}$, respectively, compared to $98 \pm 4 \mathrm{~b}$ for the control.

Notably, these results were temporal in nature, with drought-induced reduction persisting into $\mathrm{H} 2$ (day 89): reduction for leaf area was from $5817 \pm 665$ a to $3062 \pm 260 \mathrm{~b}$, for leaf number from $42 \pm 7$ a to $32 \pm 3 \mathrm{~b}$, and for shoot fresh mass from $334 \pm 40$ a to $184 \pm 2 \mathrm{~b}$, respectively, for the non-drought treatment vs. control drought treatment. Upon the different fertilizer treatments, leaf area, leaf number, and fresh shoot biomass values were improved to different extents, relative to the non-fertilized drought (control) treatment. For leaf area, the values were $4208 \pm 282 \mathrm{~b}, 3659 \pm 431 \mathrm{bc}$, and $4041 \pm 404$ $\mathrm{b}$, for the salt-soil, salt-foliar, and micnobit treatments, respectively, compared to $3062 \pm 260 \mathrm{c}$ for the control. For leaf number, the values were, for the salt-soil, salt-foliar, and micnobit treatments, respectively, $42 \pm 4 \mathrm{a}, 31 \pm 2 \mathrm{~b}$, and $36 \pm 5 \mathrm{ab}$, compared to $32 \pm 3 \mathrm{~b}$ (control), and for fresh shoot biomass $244 \pm 17 \mathrm{~b}, 202 \pm 23 \mathrm{bc}$, and $222 \pm 21 \mathrm{bc}$, respectively, compared to $184 \pm 2 \mathrm{c}$ (control).

With respect to shoot elongation, the response to drought was significant $(p=0.05)$ at the mid-growth phase (H2) as well as at physiological maturity (H3) (Fig. 2a). Subsequently, the effectiveness of $\mathrm{Zn}, \mathrm{B}$, and $\mathrm{Cu}$ in the salt and micnobit formulations in mitigating the negative effects of drought on shot elongation was demonstrated under the drought regime. As shown in Fig. 2a, treatments of salt in soil significantly mitigated the drought-induced reduction of plant height at $\mathrm{H} 2$ and $\mathrm{H} 3$, while an intermediate positive response was observed with foliar applications of salt and micnobit formulations only at $\mathrm{H} 3$; however, the foliar treatments were not significantly different from the control. For shoot biomass production under drought, dry weight (Fig. 2b) also was improved by micronutrient application, with the responses across harvest times being more dramatic with soil applied salts than foliar-applied salts and micnobits, which showed no difference between them.

As with vegetative growth, soybean reproductive parameters including pod fresh weight, pod number, fresh grain weight, grain count, and grain dry weight were also significantly impaired by drought, compared to adequate water availability. Between these two treatments, pod fresh weight was reduced by drought, from $171 \pm 23$ a to $89 \pm 4 \mathrm{~b}$ at $\mathrm{H1}$ and from $79 \pm 1$ a to $36 \pm 9 \mathrm{~b}$ at H2. Similarly, pod number and grain fresh weight at $\mathrm{H} 2$ were respectively reduced from $92 \pm 3$ a to $55 \pm 10 \mathrm{~b}$ and from $57 \pm 1$ a to $26 \pm 6 \mathrm{~b}$. Subsequently, the salt-soil, salt-foliar, and micnobit treatments under drought stress increased pod fresh weight from $89 \pm 4 \mathrm{c}$ to $121 \pm \mathrm{b}, 99 \pm 12 \mathrm{bc}$, and $109 \pm 10 \mathrm{bc}$, respectively, at $\mathrm{H} 1$ and from $36 \pm 9$ c to $52 \pm 2$ b, $49 \pm 8$ b, and $50 \pm 5$ b, respectively, at H2. Likewise, pod number and grain fresh weight at $\mathrm{H} 2$ were respectively altered by the salt-soil, salt-foliar, and micnobit treatments, relative to the control, respectively, from $55 \pm 10 \mathrm{~b}$ to $64 \pm 0.6 \mathrm{~b}, 62 \pm 5 \mathrm{~b}$, and $53 \pm 10 \mathrm{~b}$ for pod number and from $26 \pm 6 \mathrm{c}$ to $37 \pm 2 \mathrm{~b}, 35 \pm 6 \mathrm{~b}$, and $35 \pm 4 \mathrm{~b}$, for grain fresh weight.

Regarding fertilizer treatment effects under drought, grain count (Fig. 2c) and grain dry weight (Fig. 2d) were all enhanced by micronutrient application, regardless of delivery strategy (soil or foliar) or nutrient packaging (salt or micnobits). However, compared to the control, the application of the micronutrients as salts via soil was significantly more impactful than the foliar treatments, especially during the second harvest time $(\mathrm{H} 2)$. At physiological maturity (H3), all micronutrient treatments showed significantly improved reproductive parameters under drought than the control, except for pod number "(see paragraph 4 above, this section) that was not significantly altered.

The crop responses in the non-drought treatment with adequate water and balanced nutrition clearly highlight the importance of good crop management practices, in which inputs (in this case, water and balanced fertilizers) are provided at optimal levels. However, as demonstrated by the control treatment, in nature, environmental perturbations such as drought, nutrient deficiency, or imbalanced nutrition are at play, with detrimental consequences for crop productivity. Consequently, supplementation with micronutrient formulations translated into agronomic benefits, as seen in above-ground vegetative and reproductive development indices. In almost all of these cases, the formulations reduced the severity of drought, culminating in a final yield improvement by $36 \%$. These findings are in agreement not only with results from previous soybean growth studies involving individual micronutrients under no-drought conditions (e.g., Reinbott and Blevins 1995; Heitholt et al. 2002; Han et al. 2011), but also with results obtained under drought condition for other crops such as wheat and rice (Bagci et al. 2007; Ashraf et al. 2014).

\subsection{Effects of micronutrients on the temporal dynamics of NPK in shoot and grain}

Temporal uptake and translocation of NPK into soybean shoot and grain and the effects of micronutrient treatments were 

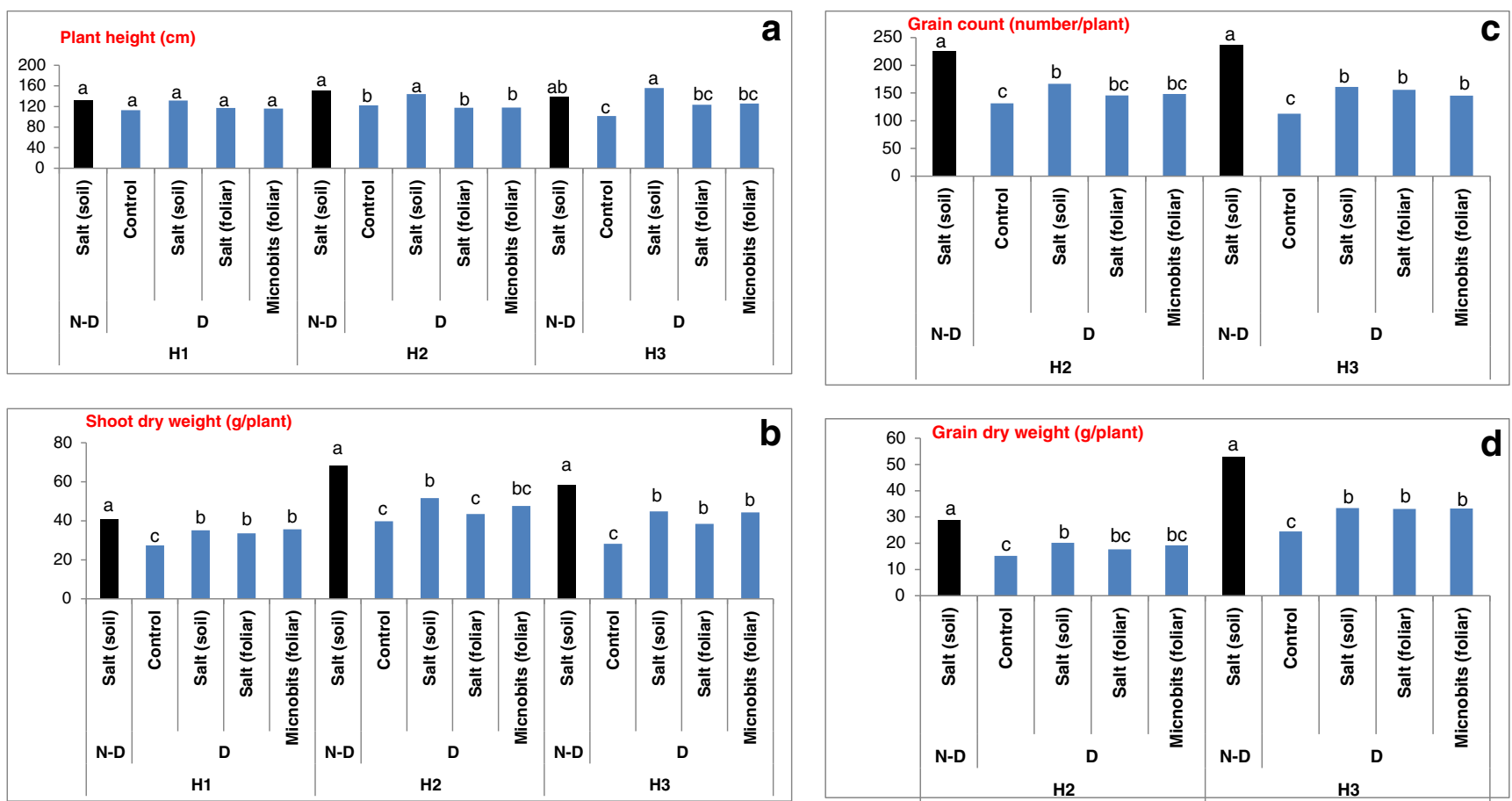

Fig. 2 Effects of composite micronutrient formulations on soybean vegetative [shoot growth (a) and biomass (b)] and reproductive [grain count (c) and grain dry weight (d)] indices under drought stress. Bars are averages, and different letters on bars represent statistically significant

differences among the treatments, separately for each harvest time $(p=0.05)(n=3)$. $N-D$ no drought, $D$ drought, $H 2$ harvest time $2, H 3$ harvest time 3

subsequently evaluated to provide a complete picture of nutrient dynamics during the crop's life cycle under drought. In Table 1, the default dynamics of these nutrients under relatively well-endowed soil condition with optimal moisture and nutrition (i.e., salt (soil)-non-drought treatment) shows a mid-term (from day 61 to day 89) increase in shoot uptake of $\mathrm{N}$ and $\mathrm{K}$ (significant in the case of $\mathrm{K}$ ) and a decline (from day 89 to day 131) in $\mathrm{N}$ and $\mathrm{K}$ uptake at physiological maturity (significant in the case of $\mathrm{N}$ ). Notably, the decline in shoot $\mathrm{N}$ uptake coincided with a significant spike in the grain uptake or translocation of $\mathrm{N}$. In contrast to $\mathrm{N}$ and $\mathrm{K}$, the shoot uptake of $\mathrm{P}$ was progressively diminished over time, albeit insignificantly, and a significantly lower grain $\mathrm{P}$ level was detected at first grain harvest (day 89), which, at physiological maturity (day 131), did not significantly exceed that of the shoot during day 61. Upon drought stress imposition, the shoot and grain uptake or translocation levels of $\mathrm{N}$ and $\mathrm{K}$ were severely diminished at all harvest times (Table 1). Drought had a remarkable effect on shoot and grain P levels, whereby shoot P uptake was slightly enhanced by drought during all three harvest times [compare soil-salt (non-drought) vs. control] but was severely lowered in the grain at both reproductive harvest times (Table 1). Compared with the control, treatment with micronutrients in soil or foliar and as salts or micnobits had variable effects on shoot uptake and grain translocation of NPK across vegetative and reproductive harvest times (Table 1). With $\mathrm{N}$ and $\mathrm{K}$, shoot and grain levels increased across board for all micronutrient treatments and all harvest times. However, this increase was only significant for shoot $\mathrm{N}$ at day 61 for all micronutrient treatments, at day 89 for soilapplied salt treatment, and for grain $\mathrm{N}$ at day 131 for all micronutrient treatments. Similarly, a significant shoot K level was found for the soil-applied salt treatment at day 89 and for grain $\mathrm{K}$ level in all micronutrient treatments at physiological maturity (day 131). With $\mathrm{P}$, there was an opposite effect of the micronutrient treatments on shoot $\mathrm{P}$ levels, wherein levels were lowered across board, significantly so with the foliar salt treatment at day 61 , with both soil and foliar salt treatments at day 89 , and with both salt and micnobits foliar treatments at day 131 . Notably, no significant effect of micronutrient treatment was found in the grain P levels under drought. The data show that a temporal dynamics played out in NPK uptake/ translocation under FMC that was mimicked under drought but differently influenced by the treatments. In the case of $\mathrm{N}$ and $\mathrm{K}$, the mid-vegetative (day 89) and physiological maturity phases (day 131) each represented a phase for measurably high nutrient contents, for shoot and grains. These observations for shoot were contrary to those of Scheiner et al. (2000) who reported maximum shoot $\mathrm{N}$ and $\mathrm{K}$ accumulation at the end of soybean vegetative growth in non-drought system. Notable also is that at the end of the vegetative growth cycle (day 131), significant amounts of $\mathrm{N}$ and $\mathrm{K}$ had been translocated to the grain, ostensibly to provide nutrition for the maturing grains. The sharp dip in the shoot $\mathrm{N}$ values at 
Table 1 Influence of drought and micronutrients on the temporal dynamics of NPK uptake into shoot and translocation into grain in soybean

\begin{tabular}{|c|c|c|c|c|c|}
\hline Treatment/nutrient/day & Salt (soil) non-drought & Control drought & Salt (soil) drought & Salt (foliar) drought & $\begin{array}{l}\text { Micnobits } \\
\text { (foliar) drought }\end{array}$ \\
\hline \multicolumn{6}{|l|}{ Nitrogen (mg/plant) } \\
\hline Shoot (day 61) & $1146 \mathrm{aC}$ & $693 \mathrm{cB}$ & $956 \mathrm{bB}$ & $934 \mathrm{bCB}$ & $915 \mathrm{bB}$ \\
\hline Shoot (day 89) & $1484 \mathrm{aBC}$ & $778 \mathrm{cB}$ & $1035 \mathrm{bB}$ & $877 \mathrm{bcCB}$ & 944 bcB \\
\hline Shoot (day 131) & $511 \mathrm{aD}$ & $326 \mathrm{bC}$ & $451 \mathrm{abC}$ & $360 \mathrm{abC}$ & $439 \mathrm{abC}$ \\
\hline Total shoot average & $1047 \mathrm{a}$ & $599 \mathrm{c}$ & $814 \mathrm{~b}$ & $724 b$ & $766 \mathrm{~b}$ \\
\hline Grain (day 89) & $1809 \mathrm{aB}$ & $941 \mathrm{bB}$ & $1149 \mathrm{bB}$ & $1060 \mathrm{bB}$ & $1159 \mathrm{bB}$ \\
\hline Grain (day 131) & $2915 \mathrm{aA}$ & $1390 \mathrm{cA}$ & $2101 \mathrm{bA}$ & $1978 \mathrm{bA}$ & $1981 \mathrm{bA}$ \\
\hline Total grain average & $2362 \mathrm{a}$ & $1166 \mathrm{c}$ & $1625 \mathrm{~b}$ & $1520 \mathrm{~b}$ & $1570 \mathrm{~b}$ \\
\hline \multicolumn{6}{|l|}{ Phosphorus (mg/plant) } \\
\hline Shoot (day 61) & $227 \mathrm{abAB}$ & $261 \mathrm{aA}$ & $204 \mathrm{abA}$ & $166 \mathrm{bA}$ & $204 \mathrm{abA}$ \\
\hline Shoot (day 89) & $200 \mathrm{abB}$ & $244 \mathrm{aAB}$ & $181 \mathrm{bA}$ & $128 \mathrm{cA}$ & $202 \mathrm{abA}$ \\
\hline Shoot (day 131) & $182 \mathrm{abB}$ & $203 \mathrm{aB}$ & $142 \mathrm{abAB}$ & $73 \mathrm{cB}$ & $129 \mathrm{bcBC}$ \\
\hline Total shoot average & $203 \mathrm{ab}$ & $236 \mathrm{a}$ & $176 \mathrm{~b}$ & $122 \mathrm{c}$ & $178 \mathrm{~b}$ \\
\hline Grain (day 89) & $123 \mathrm{aC}$ & $76 \mathrm{bD}$ & $89 \mathrm{bB}$ & $77 \mathrm{bB}$ & $91 \mathrm{bC}$ \\
\hline Grain (day 131) & $275 \mathrm{aA}$ & $128 \mathrm{bC}$ & $177 \mathrm{bA}$ & $151 \mathrm{bA}$ & $179 \mathrm{bAB}$ \\
\hline Total grain average & $199 \mathrm{a}$ & $102 \mathrm{~b}$ & $134 \mathrm{~b}$ & $114 \mathrm{~b}$ & $135 \mathrm{~b}$ \\
\hline \multicolumn{6}{|l|}{ Potassium (mg/plant) } \\
\hline Shoot (day 61) & $893 \mathrm{aB}$ & $584 \mathrm{bAB}$ & $759 \mathrm{abAB}$ & $745 \mathrm{abA}$ & $677 \mathrm{bAB}$ \\
\hline Shoot (day 89) & $1163 \mathrm{aA}$ & $697 \mathrm{cA}$ & $877 \mathrm{bA}$ & $739 \mathrm{bcA}$ & $791 \mathrm{bcA}$ \\
\hline Shoot (day 131) & $989 \mathrm{aAB}$ & $602 \mathrm{bAB}$ & $770 \mathrm{bAB}$ & $656 \mathrm{bA}$ & $732 \mathrm{bAB}$ \\
\hline Total shoot average & $1015 \mathrm{a}$ & $628 \mathrm{c}$ & $802 \mathrm{~b}$ & $713 \mathrm{bc}$ & $733 \mathrm{~b}$ \\
\hline Grain (day 89) & $559 \mathrm{aC}$ & $300 \mathrm{bC}$ & $375 \mathrm{bC}$ & $344 \mathrm{bB}$ & $379 \mathrm{bC}$ \\
\hline Grain (day 131) & $982 \mathrm{aB}$ & $459 \mathrm{cB}$ & $659 \mathrm{bB}$ & $626 \mathrm{bA}$ & $632 \mathrm{bB}$ \\
\hline Total grain average & $771 \mathrm{a}$ & $380 \mathrm{c}$ & $517 \mathrm{~b}$ & $485 \mathrm{~b}$ & $506 \mathrm{~b}$ \\
\hline
\end{tabular}

Values are averages, and different letters with values represent statistically significant differences among the treatments on each harvest day (lowercase; in rows) and across harvest days for each treatment (uppercase; in columns), separately for each nutrient $(p=0.05)(n=3)$. Total averages are means from the three replicates of all three (shoot) or two (grain) harvest days; different letters after the values represent statistically significant differences among the treatments

this time could be owing to (i) the high amounts of fallen leaves due to senescence (data not shown), which reduced the total measurable shoot $\mathrm{N}$, and/or (ii) the possibility of remobilization of $\mathrm{N}$ from senescing leaves to seeds (Masclaux-Daubresse et al. 2010, and references therein). Unlike N, however, a possible effect of senescence on shoot $\mathrm{K}$ influencing $\mathrm{K}$ remobilization to seeds was not found, as no significant changes occurred between the final vegetative and final reproductive $\mathrm{K}$ contents. Contrary to the bell-shaped vegetative $\mathrm{N}$ and $\mathrm{K}$ uptake dynamics in other treatments, the salt foliar treatment showed a linear drop in shoot $\mathrm{N}$ content, but no effect on shoot $\mathrm{K}$ dynamics. It is unclear at this point why this treatment, and not the soil-applied salts, nor micnobits differentially altered shoot $\mathrm{N}$ dynamics. The overall $\mathrm{P}$ dynamics differed from that of $\mathrm{N}$ or $\mathrm{K}$ in that peak $\mathrm{P}$ uptake occurred at early vegetative stage, reflecting the importance of $\mathrm{P}$ in early plant development, in which $\mathrm{P}$ deficiency could reduce the rate of leaf emergence and leaf size (Nadeem et al. 2011). Although grain $P$ level was initially low in the immature grain (day 89), at full reproductive maturity, the grain $\mathrm{P}$ translocation increased remarkably, perhaps also reflective of the high $P$ requirement of seeds in early initiation of future shoot development.

\subsection{Effects of treatment type on the shoot-grain dynamics of $\mathrm{Zn}, \mathrm{B}$, and $\mathrm{Cu}$}

The temporal shoot-grain dynamics of $\mathrm{Zn}$ and $\mathrm{Cu}$ were not significantly altered by soil moisture condition (non-drought or drought imposition); about as much $\mathrm{Zn}$ or $\mathrm{Cu}$ that was taken up into the shoot ended up in the grain under each condition; however, translocation of $\mathrm{Zn}$ or $\mathrm{Cu}$ to grain was significantly diminished by drought compared to non-drought, as indicated by grain $\mathrm{Zn}$ and $\mathrm{Cu}$ values at days 89 and 131 (Table 2). In contrast, for B, a notable plant age-dependent increase in shoot B uptake was evident under all treatment conditions, with overall shoot $B$ uptake being significantly different than grain translocation, wherein less than $50 \%$ translocation from shoot to grain was 
Table 2 Influence of drought and micronutrients on the temporal dynamics of $\mathrm{Zn}, \mathrm{B}$, and $\mathrm{Cu}$ uptake into shoot and translocation into grain in soybean

\begin{tabular}{|c|c|c|c|c|c|}
\hline Treatment/nutrient/day & Salt (soil) non-drought & Control drought & Salt (soil) drought & Salt (foliar) drought & $\begin{array}{l}\text { Micnobits } \\
\text { (foliar) drought }\end{array}$ \\
\hline \multicolumn{6}{|l|}{ Zinc (mg/plant) } \\
\hline Shoot (day 61) & $0.79 \mathrm{cB}$ & $0.48 \mathrm{cA}$ & $0.82 \mathrm{cA}$ & $9.35 \mathrm{aA}$ & $6.54 \mathrm{bA}$ \\
\hline Shoot (day 89) & $1.75 \mathrm{cA}$ & $0.36 \mathrm{cA}$ & $0.88 \mathrm{cA}$ & $8.39 \mathrm{aAB}$ & $6.50 \mathrm{bA}$ \\
\hline Shoot (day 131) & $1.13 \mathrm{cAB}$ & $0.52 \mathrm{cA}$ & $0.64 \mathrm{cA}$ & $7.91 \mathrm{aB}$ & $6.05 \mathrm{bA}$ \\
\hline Total shoot average & $1.22 \mathrm{c}$ & $0.45 \mathrm{c}$ & $0.64 \mathrm{c}$ & $8.55 \mathrm{a}$ & $6.36 \mathrm{~b}$ \\
\hline Grain (day 89) & $0.68 \mathrm{aB}$ & $0.29 \mathrm{cA}$ & $0.48 \mathrm{bA}$ & $0.44 \mathrm{bcC}$ & $0.34 \mathrm{cC}$ \\
\hline Grain (day 131) & $1.09 \mathrm{aAB}$ & $0.39 \mathrm{dA}$ & $0.79 \mathrm{bA}$ & $0.76 \mathrm{bC}$ & $0.59 \mathrm{cB}$ \\
\hline Total grain average & $0.89 \mathrm{a}$ & $0.34 \mathrm{~d}$ & $0.64 \mathrm{~b}$ & $0.60 \mathrm{~b}$ & $0.47 \mathrm{c}$ \\
\hline \multicolumn{6}{|l|}{ Boron (mg/plant) } \\
\hline Shoot (day 61) & $2.01 \mathrm{aC}$ & $0.86 \mathrm{cC}$ & $2.00 \mathrm{aC}$ & $1.81 \mathrm{abC}$ & $1.48 \mathrm{bC}$ \\
\hline Shoot (day 89) & $2.78 \mathrm{aB}$ & $1.36 \mathrm{cB}$ & $2.67 \mathrm{aB}$ & $2.17 \mathrm{bB}$ & $1.88 \mathrm{bB}$ \\
\hline Shoot (day 131) & $3.49 \mathrm{aA}$ & $1.64 \mathrm{cA}$ & $3.24 \mathrm{aA}$ & $2.49 \mathrm{bA}$ & $2.45 \mathrm{bA}$ \\
\hline Total shoot average & $2.76 \mathrm{a}$ & $1.29 \mathrm{c}$ & $2.64 \mathrm{a}$ & $2.16 \mathrm{~b}$ & $1.94 \mathrm{~b}$ \\
\hline Grain (day 89) & $0.06 \mathrm{aD}$ & $0.02 \mathrm{bD}$ & $0.03 \mathrm{bE}$ & $0.02 \mathrm{bE}$ & $0.02 \mathrm{bE}$ \\
\hline Grain (day 131) & $1.71 \mathrm{aC}$ & $0.68 \mathrm{cC}$ & $1.08 \mathrm{bD}$ & $1.06 \mathrm{bD}$ & $1.06 \mathrm{bD}$ \\
\hline Total grain average & $0.89 \mathrm{a}$ & $0.35 \mathrm{c}$ & $0.56 \mathrm{~b}$ & $0.54 \mathrm{~b}$ & $0.54 \mathrm{~b}$ \\
\hline \multicolumn{6}{|l|}{ Copper (mg/plant) } \\
\hline Shoot (day 61) & $0.18 \mathrm{cB}$ & $0.13 \mathrm{cB}$ & $0.23 \mathrm{cA}$ & $3.52 \mathrm{aA}$ & $2.97 \mathrm{aA}$ \\
\hline Shoot (day 89) & $0.35 \mathrm{cA}$ & $0.19 \mathrm{cAB}$ & $0.2 \mathrm{cAB}$ & $3.41 \mathrm{aA}$ & $2.80 \mathrm{bA}$ \\
\hline Shoot (day 131) & $0.28 \mathrm{cAB}$ & $0.32 \mathrm{cA}$ & $0.21 \mathrm{cAB}$ & $3.30 \mathrm{aA}$ & $3.05 \mathrm{bA}$ \\
\hline Total shoot average & $0.27 \mathrm{~b}$ & $0.21 \mathrm{~b}$ & $0.21 \mathrm{~b}$ & $3.41 \mathrm{a}$ & $2.94 \mathrm{a}$ \\
\hline Grain (day 89) & $0.15 \mathrm{aB}$ & $0.10 \mathrm{bB}$ & $0.10 \mathrm{bC}$ & $0.12 \mathrm{abB}$ & $0.1 \mathrm{bB}$ \\
\hline Grain (day 131) & $0.21 \mathrm{aB}$ & $0.13 \mathrm{bB}$ & $0.15 \mathrm{bcBC}$ & $0.20 \mathrm{acB}$ & $0.13 \mathrm{bB}$ \\
\hline Total grain average & $0.18 \mathrm{a}$ & $0.12 \mathrm{~b}$ & $0.13 \mathrm{~b}$ & $0.16 \mathrm{a}$ & $0.12 \mathrm{~b}$ \\
\hline
\end{tabular}

Values are averages, and different letters with values represent statistically significant differences among the treatments on each harvest day (lowercase; in rows) and across harvest days for each treatment (uppercase; in columns), separately for each nutrient $(p=0.05)(n=3)$. Total averages are means from the three replicates of all three (shoot) or two (grain) harvest days; different letters after the values represent statistically significant differences among the treatments

observed at physiological maturity, regardless of soil moisture condition. Moreover, drought stress significantly diminished B uptake and translocation throughout the growth period of the plants (Table 2). Treatment of the salt formulation in soil under drought caused no change in $\mathrm{Zn}$ shoot-grain dynamics, whereas the foliar treatments of both salts and micnobits showed inefficient translocation of $\mathrm{Zn}$ to the grain, with only about $10 \%$ of $\mathrm{Zn}$ in shoot being translocated to grain at full maturity. With $\mathrm{B}$, the general shoot-grain dynamics found under drought in the absence of the formulations was largely maintained among the treatments, with between $34 \%$ (for the soil-salt) and $43 \%$ (for both foliar treatments) of shoot B translocated to the grain at full maturity. For $\mathrm{Cu}$ under drought condition, $50-70 \%$ was translocated from shoot to grain upon salt treatment in soil, whereas with both foliar treatments, no more than $6 \%$ of the shoot $\mathrm{Cu}$ was translocated to the grain during plant growth (Table 2), possibly highlighting a strong difference in translocation to the grain from soil vs. shoot application, which appears to be specific for $\mathrm{Cu}$. Although $\mathrm{Zn}, \mathrm{B}$, and $\mathrm{Cu}$ are all considered relatively plant-immobile elements, the shoot-grain $\mathrm{Zn}, \mathrm{B}$, and $\mathrm{Cu}$ dynamics observed in this study highlight clear differences in their levels of mobility in terms of metals $(\mathrm{Zn}$ and $\mathrm{Cu})$ and non-metal (B). This can be easily demonstrated in the soil treatments where, at physiological maturity, about similar levels of $\mathrm{Zn}$ and $\mathrm{Cu}$ were found in shoot as in grain, but not for B. Clearly, the consistent pattern of increasing B in the shoot as the plants aged indicates a higher degree of $\mathrm{B}$ mobility, compared to $\mathrm{Zn}$ and $\mathrm{Cu}$. Similar pattern of B translocation was found in soybean under non-drought condition (Ross et al. 2006), as well as in peanut (Konsaeng et al. 2010).

\subsection{Effects of micronutrient formulations on shoot total nutrient uptake}

Shoot nutrient profile was determined in order to understand the uptake of the added nutrients as well as any potential synergisms or antagonisms with the uptake of other nutrients. In the non-drought vs. drought treatments, the total uptake of 
the macronutrients $\mathrm{N}$ and $\mathrm{K}$ was significantly $(p=0.05)$ inhibited by drought (Table 1; total shoot averages). Similarly, S uptake was significantly inhibited by drought, reducing from $64 \pm 3$ a in the non-drought treatment to $40 \pm 2 \mathrm{~b}$ in the control (values in $\mathrm{mg} / \mathrm{plant}$ ). In contrast to $\mathrm{N}$, $\mathrm{K}$, and $\mathrm{S}$, a slight but insignificant increase in $\mathrm{P}$ uptake was observed in the drought-stressed plants relative to the nonstressed ones (Table 1; total shoot averages). Notably, no effect of drought was observed for $\mathrm{Ca}$ or $\mathrm{Mg}$ uptake (data not shown). With micronutrient fertilization under drought stress, the uptake of $\mathrm{N}, \mathrm{K}$, and $\mathrm{S}$ into shoot from the micronutrienttreated plants was higher compared to the control. This increase was significant in the case of $\mathrm{N}$ in all treatments (Table 1; total shoot averages) and for $\mathrm{K}$ in the soil-salt and micnobit treatments, but not in the salt-foliar one (Table 1; total shoot averages). Uptake of S was significantly enhanced only in the salt-soil treatment ( $54 \pm 7 \mathrm{a} \mathrm{mg,} \mathrm{compared} \mathrm{to} 40 \pm 2$ $\mathrm{b}$ in the control). In contrast to $\mathrm{N}, \mathrm{K}$, and $\mathrm{S}$, the uptake of $\mathrm{P}$ under drought was significantly suppressed by all micronutrient treatments (Table 1; total shoot averages). Contrary to NPKS, micronutrient fertilization did not have any effects on $\mathrm{Ca}$ or Mg uptake (data not shown).

With respect to micronutrients in shoot, total uptake of B (Table 2; total shoot averages) and $\mathrm{Mn}(5.59 \pm 0.4$ a vs. $3.52 \pm 0.5 \mathrm{~b} \mathrm{mg}$ ) was significantly inhibited by drought, relative to the non-drought treatment. In contrast, a statistically nonsignificant reduction was observed for $\mathrm{Zn}$, while none was obtained for $\mathrm{Cu}$ (Table 2; total shoot averages), as well as for $\mathrm{Fe}$ and Mo (data not shown). In the micronutrient-fertilized drought-stressed plants, however, the uptake of $\mathrm{Zn}$ was significantly improved by foliar application, wherein the highest effect was seen in the salt treatment than by micnobits, while a slight, albeit insignificant increase in $\mathrm{Zn}$ uptake was observed from the soil treatment with salt (Table 2; total shoot averages). Thus, foliar treatment of salts was overall more effective in increasing shoot $\mathrm{Zn}$ content than soil treatment. The uptake of $\mathrm{B}$ under drought was significantly promoted in all treatments, with the salt-soil treatment showing the best result (Table 2; total shoot averages). In contrast to $\mathrm{B}$, uptake of $\mathrm{Cu}$ under drought was significantly enhanced by foliar-salt and micnobit treatments, differing from the soil-salt treatment where no effect was seen (Table 2; total shoot averages). Relative to the control, the uptake of Mn was similarly significantly enhanced in the soil-salt and micnobits (from $3.52 \pm 0.5 \mathrm{~b} \mathrm{mg}$ in the control, to $4.43 \pm 0.3 \mathrm{a}$ and $4.74 \pm 0.6 \mathrm{a} \mathrm{mg}$, respectively) than in the foliar-salt treatment ( $3.64 \pm 0.3$ a compared to $3.52 \pm 0.5$ a mg). Thus, soil application of salts supported more Mn uptake than foliar, while the micnobits were more effective as foliar fertilizers than salts. Unlike $\mathrm{Mn}, \mathrm{Fe}$ and Mo uptake under drought was not significantly affected by all formulation treatments (data not shown).

Alterations in $\mathrm{Zn}$ or $\mathrm{Cu}$ homeostasis affecting macronutrient and micronutrient levels in plants have previously been demonstrated under normal water regimes (see, for example, Dimkpa et al. 2015). With these results, we show in soybean further evidence of this phenomenon under drought stress using a composite of $\mathrm{Zn}, \mathrm{Cu}$, and $\mathrm{B}$ as nanoparticles or salts. The findings of increased shoot uptake of $\mathrm{Zn}, \mathrm{B}$, and $\mathrm{Cu}$ are in agreement with studies reporting increases in plant uptake of these nutrients when applied via soil or foliar and where also the enhanced uptake of non-applied micronutrients (in this case Mn) was observed (see studies reviewed in Dimkpa and Bindraban 2016). Although nanoparticulate nutrients applied as foliar treatments are difficult to completely eliminate from leaf surfaces by washing protocols (Hong et al. 2014), the finding that shoot $\mathrm{Zn}, \mathrm{B}$, and $\mathrm{Cu}$ levels in the micnobittreated shoots were not greater than those in the salt treatments precludes any likelihood that the shoot values for $\mathrm{Zn}, \mathrm{B}$, and $\mathrm{Cu}$ in the micnobit treatment were exaggerated due to leaf surface-adsorbed micronutrients from the foliar treatments.

The uptake of $\mathrm{N}$ in this study is noteworthy due to its reported mediocre uptake efficiency (50\%) among different crops (Baligar et al. 2001), which as we observed in this study could be worsened by drought. However, by applying micronutrients, we could, on average, cut the droughtinduced $43 \%$ reduction in $\mathrm{N}$ uptake down to $17 \%$, while raising $\mathrm{N}$ uptake by $28 \%$, relative to the level under drought stress. This enhancing effect could be either due to (i) a direct action of the micronutrients on $\mathrm{N}$ uptake as reported for wheat grown in a salt-affected soil using $\mathrm{Zn}$ and $\mathrm{Cu}$ (about $2.5 \mathrm{mg} / \mathrm{kg}$, each; Manzoor et al. 2014), (ii) the micronutrients indirectly enhancing the activity of $\mathrm{N}$-fixing bacteria in the soybean (Eisa and Ali 2014), or both. Viewed in a broader context, a reduction in the uptake of $\mathrm{N}$ by plants implies its loss to the soil or atmosphere, increasing its involvement in climate change and eutrophication-related events. Our data, thus, demonstrate a clear role for micronutrient formulations in curtailing $\mathrm{N}$ loss, which can be applied in an integrated $\mathrm{N}$ management strategy. In particular, the mitigation of $\mathrm{N}$ loss by foliar micronutrient sprays could have even more significant implications under drought scenario where, apparently, $\mathrm{N}$, like most other nutrients, becomes less bioavailable from the soil.

The results for $\mathrm{P}$ uptake are also noteworthy, at least for two seemingly contradictory reasons. On the one hand, the generally reported $\mathrm{P}$ uptake efficiency is abysmally low, $<10 \%$ (Baligar et al. 2001), and here, we also found $P$ uptake by soybean even under non-drought condition to be low, compared to $\mathrm{N}$ and $\mathrm{K}$. In prior studies devoid of drought stress, Barik and Chandel (2006) reported an increase (19.4 kg/ha; up by $11 \%)$ and then a lowering $(13.8 \mathrm{~kg} /$ ha; down by $21 \%)$ of total P uptake (shoot + grain) by soybean under low $(2.5 \mathrm{~kg} /$ ha) and high (10 kg/ha) $\mathrm{Cu}$ doses, respectively. Thus, even though the micronutrient formulations lowered shoot $\mathrm{P}$ uptake in our study, at a similar $\mathrm{Cu}$ dose of $1.3 \mathrm{mg} / \mathrm{kg}(\approx 2.6 \mathrm{~kg} / \mathrm{ha})$ that we used, average $\mathrm{P}$ uptake (shoot + grain) under the 
micronutrient treatments is still high $(207 \mathrm{mg} /$ plant $=72 \mathrm{~kg} /$ ha; assuming a soybean density of $350,000 /$ ha) relative to values reported by Barik and Chandel (2006). However, when compared to the control treatment under drought, our data clearly show that the composite micronutrients lowered shoot $\mathrm{P}$ uptake. The suppression of $\mathrm{P}$ uptake by the micronutrients under drought occurred regardless of whether soil or foliar applied. Thus, the effect seems to be plant-organ independent. Our finding raises the broader question whether in droughtprone soils, the uptake of $\mathrm{P}$ could be impeded by fertilizer products containing certain micronutrient mixtures, with the potentially inimical environmental consequences of excess $P$ stockpiling in the soil. On the other hand, the reduction in plant uptake of $\mathrm{P}$ could be due to specific interactions of micronutrients in the formulations with P. Indeed, our data suggest this to be likely, given that lowered $\mathrm{P}$ uptake in the shoot corresponded to an increase in $\mathrm{Zn}$ and, to a lesser extent, $\mathrm{Cu}$ levels. The finding of lowered $\mathrm{P}$ uptake with addition of the $\mathrm{Zn}$-containing fertilizer formulations could have beneficial ramifications for $\mathrm{P}-\mathrm{Zn}$ interactions with respect to plant nutritional quality. P-Zn interaction results in the formation of $\mathrm{Zn}$ phosphate in different plants and plant organs, including soybean (Raboy and Dickinson 1984), wheat (Dimkpa et al. 2013), and maize (Lv et al. 2014). Such Zn-P complexes exist, presumably, in the Zn-phytate form (Raboy and Dickinson 1984; Lv et al. 2014) in which Zn bioavailability can be significantly hampered (see, for example, Dominguez et al. 2002). The specific involvement of $Z n$ is further suggested in the higher shoot $\mathrm{P}$, but lower shoot $\mathrm{Zn}$ uptake in the control treatment compared to the soil-salt, and agrees with other studies where reduced $\mathrm{P}$ uptake with $\mathrm{Zn}$ fertilization has been reported (e.g., Bouain et al. 2014; Watts-Williams et al. 2014). If indeed $\mathrm{Zn}$ is involved in the suppression of $\mathrm{P}$ uptake, then the $\mathrm{Zn}$ ions seem more culpable than micnobit $\mathrm{Zn}$, as indicated by the higher level of $\mathrm{Zn}$ and correspondingly lower level of $\mathrm{P}$ in the salt vs. micnobit foliar treatments. This is not exactly surprising as $\mathrm{Zn}$ ions from the micnobits would first have to be released through particle dissolution, prior to any interaction with $\mathrm{P}$. However, the question arises as to whether an inhibition of $\mathrm{P}$ by $\mathrm{Zn}$ such as is being suggested here is perhaps more relevant for leafy vegetable crops than grain crops such as soybean, given that $\mathrm{P}$ translocation into grain and final grain $\mathrm{P}$ concentration were not negatively influenced by the micronutrient treatments unlike shoot uptake.

\subsection{Effects of micronutrient formulations on total nutrient translocation into grain}

To understand nutrient translocation into the grain under the influence of drought and micronutrient fortification, the nutrient contents of grains were determined. Total grain levels of $\mathrm{N}, \mathrm{P}$, and $\mathrm{K}$ (Table 1; total grain averages), as well as those of $\mathrm{S}(248 \pm 11$ vs. $118 \pm 21 \mathrm{mg}), \mathrm{Mg}(178 \pm 14$ vs. $90 \pm 11 \mathrm{mg})$, and $\mathrm{Ca}(199 \pm 11$ vs. $113 \pm 6 \mathrm{mg})$, were significantly higher in the non-drought plants, compared to the control plants under drought stress. Under drought, all micronutrient treatments significantly elevated grain $\mathrm{N}$ and $\mathrm{K}$ levels (Table 1; total grain averages). In contrast, there was no effect of micronutrient treatment on grain P level. The levels of other macronutrients under drought, namely $\mathrm{S}, \mathrm{Ca}$, and $\mathrm{Mg}$, were all enhanced by micronutrition. However, the effects were significant only with soil-salt and micnobit treatments for $\mathrm{S}$ and $\mathrm{Mg}$, $160 \pm 6$ and $120 \pm 10 \mathrm{mg}$ and $157 \pm 7$ and $117 \pm 9 \mathrm{mg}$, respectively, and with micnobits for $\mathrm{Ca}(141 \pm 12 \mathrm{mg})$. In the case of micronutrients, grain translocation of $\mathrm{Zn}, \mathrm{B}$, and $\mathrm{Cu}$ (Table 2; total grain averages) as well as that of $\mathrm{Fe}$ (from $8.27 \pm 3.9$ to $3.83 \pm 0.3 \mathrm{mg}$ ) and $\mathrm{Mn}$ (from $3.68 \pm 0.3$ to $1.98 \pm 0.1 \mathrm{mg}$ ) was negatively impacted by drought. Under drought, grain $\mathrm{Zn}$ and B levels were significantly enhanced by all treatments but, in the case of $\mathrm{Cu}$, only by foliar salts (Table 2; total grain averages). Grain Mn level was enhanced by both foliar treatments, significantly so by the micnobits $(2.51 \pm 0.3$ vs. $1.98 \pm 0.1 \mathrm{mg}$, for the control). In contrast, no effect of micronutrient treatments was observed for grain Fe. The previous effects of drought and micronutrient treatments on nutrient translocation to grain are in agreement with previous studies. While a recent report (Karim and Rahman 2015) involving treatments of earlier-soil and later-foliar applications of $\mathrm{Zn}, \mathrm{B}$, and $\mathrm{Mn}$ highlighted increases in the grain micronutrient concentration, as well as grain yield of maize, rice, and wheat under drought, for soybean, the enhancement of $\mathrm{Zn}, \mathrm{B}$, or $\mathrm{Cu}$ translocation to grain upon soil or foliar treatments is known only for non-drought growth conditions. As examples, up to $43 \mathrm{mg} \mathrm{Zn/kg,} 22 \mathrm{mg} \mathrm{Cu} / \mathrm{kg}$, or $21 \mathrm{mg} \mathrm{B} / \mathrm{kg}$ grain concentrations can be obtained, respectively, from applying ranges of $\mathrm{Zn}(0.3-2.4 \mathrm{mg} / \mathrm{kg}), \mathrm{Cu}(1.25-5 \mathrm{mg} / \mathrm{kg})$, or B $(0.25-1.25 \mathrm{mg} / \mathrm{kg})$, dependent on specific application rate and on soybean variety (Ross et al. 2006; Inocêncio et al. 2012; Enderson et al. 2015). In the present study, using Zn, B, and $\mathrm{Cu}$ rates that are in the vicinity of these reported ranges, we obtained, on average, $22 \mathrm{~g} \mathrm{Zn} / \mathrm{kg}, 32 \mathrm{~g} \mathrm{~B} / \mathrm{kg}$, and $5 \mathrm{~g} \mathrm{Cu} / \mathrm{kg}$ grain, respectively. Nevertheless, except for $\mathrm{Cu}$, these values are significant improvements, relative to the drought control without micronutrient treatment. These differences further highlight the species dependency of nutrient uptake and/or potential interactions between $\mathrm{Zn}$ and $\mathrm{Cu}$ in the formulations (Dimkpa et al. 2015).

\subsection{Effects of micronutrient formulations on grain mineral nutrition quality}

The nutrient concentrations per gram of dry grain were determined for the final harvest in order to assess the potential, under drought condition, for the fertilizer formulations and delivery methods to modulate the mineral nutritional quality of the edible soybean produce. As indicated in Fig. 3a, the 
nutritional quality of the grains in terms of NPK concentrations was not significantly affected by drought or by the micronutrient treatments. Similarly, there was no effect of drought or micronutrient treatment on grain $\mathrm{Mg}, \mathrm{Ca}$, and $\mathrm{S}$ concentrations (data not shown). However, the dry grain concentrations of $\mathrm{Zn}$ and $\mathrm{B}$ were significantly reduced by drought, but under drought, each was significantly elevated by the different treatments of micronutrients, relative to the control treatment (Fig. 3b). Notably, the grain concentration of $\mathrm{Cu}$ was significantly enhanced under drought [compare saltsoil (non-drought) vs. control) but was lowered significantly by the micnobit treatment under drought (Fig. 3b). A similar result as $\mathrm{Cu}$ was obtained for $\mathrm{Fe}$ under drought, but while the salt treatments diminished grain Fe concentration, there was no effect of micnobits (data not shown). With grain Mn concentration, there was no effect of drought or micronutrient treatments; however, a significantly higher grain $\mathrm{Mn}$ was seen in the micnobits, relative to the foliar-salt treatment (data not shown). At first glance, the actual dry grain NPK concentrations would appear to not support the shoot uptake and grain translocation patterns of these nutrients under the micronutrient treatments. However, a look at the different grain
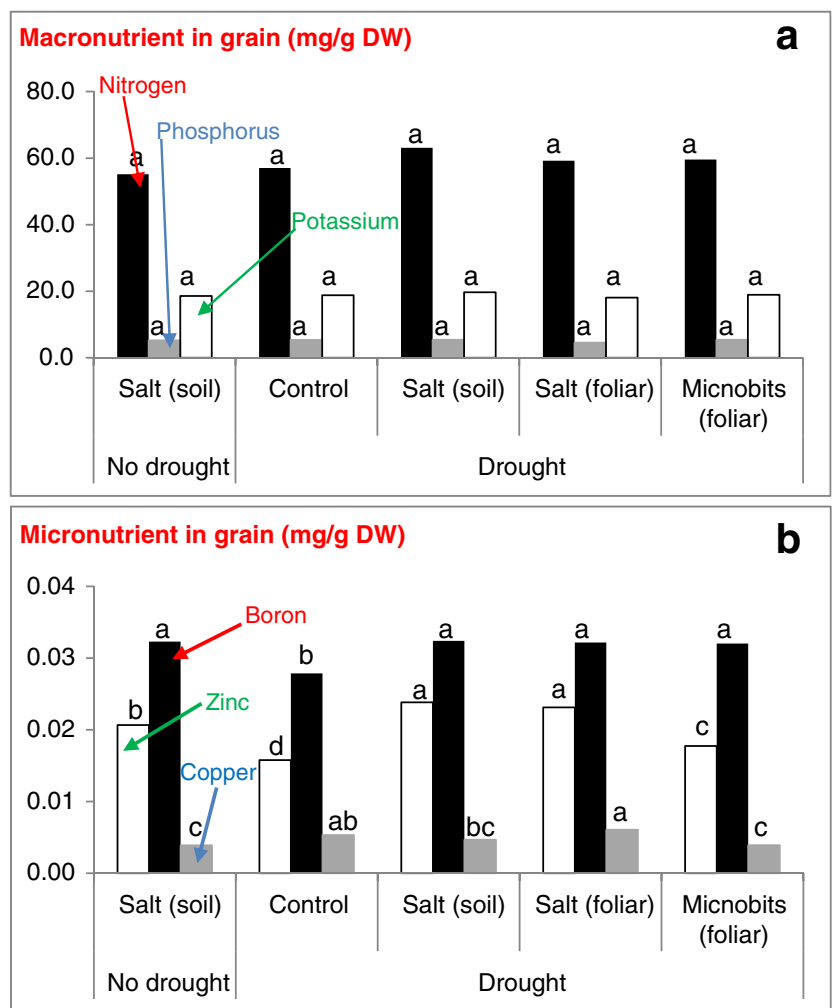

Fig. 3 Effects of composite micronutrient formulations on the grain concentrations (g per dry weight) of a NPK (nitrogen (black), phosphorus (gray), potassium (white)) and b $\mathrm{Zn}, \mathrm{B}$, and $\mathrm{Cu}$ (zinc (white), boron (black), copper (gray)) of soybean at full physiological maturity under drought stress. Bars are averages, and different letters on bars represent statistically significant differences among the treatments $(p=0.05)(n=3)$ biomasses at full physiological maturity (Fig. 2b) would indicate that the NPK concentrations corresponded with the grain biomasses across the non-drought and drought conditions. Nevertheless, for the micronutrients, grain $\mathrm{Zn}$ and B concentrations under drought remained above those of the control, even surpassing (for $\mathrm{Zn}$, exempting the micnobits) or equaling (for B) those obtained under non-drought condition. Notably, under non-drought condition, Enderson et al. (2015) reported significant increases in soybean grain $\mathrm{Zn}, \mathrm{Cu}$, or $\mathrm{B}$ content upon foliar treatments of mixtures of $\mathrm{Zn}, \mathrm{Cu}, \mathrm{B}$, and $\mathrm{Mn}$ from commercial sources. And Samarah et al. (2004) also found increases in soybean grain $\mathrm{Zn}, \mathrm{Cu}$, and $\mathrm{Mn}$ concentrations accumulated from unfertilized soil under drought. Such enhanced increases in grain $\mathrm{Zn}$ concentration (in our case by $23 \%$, under drought) represent an agronomic strategy to fortify food produce, with broader implications for nutrition security, especially for developing countries where human $\mathrm{Zn}$ deficiency is rampant (Joy et al. 2015; Dimkpa and Bindraban 2016).

\subsection{Correlating micronutrient and macronutrient levels in grain and micronutrient uptake and yield}

In order to ascertain the relative influence under drought stress of each of the micronutrients in the formulations on NPK translocation into grain and grain yield at physiological maturity, the relationships between (i) grain translocation of $\mathrm{Zn}, \mathrm{B}$, and $\mathrm{Cu}$ and those of NPK and (ii) the relationships between shoot $\mathrm{Zn}, \mathrm{B}$, and $\mathrm{Cu}$ uptake and grain yield at physiological maturity were determined. In the first case, grain uptake, rather than shoot uptake, was used for this analysis to exclude any confounding effect from the foliar, compared to the soil application. For the same reason, the foliar treatments were excluded in the second scenario. These correlations show the following: (i) a strong relationship between grain $\mathrm{N}$ and $\mathrm{B}\left(r^{2}=0.98\right)$ and, to a lesser extent, grain $\mathrm{N}$ and $\mathrm{Zn}\left(r^{2}=0.72\right)$; (ii) a strong correlation between grain $\mathrm{K}$ and $\mathrm{B}\left(r^{2}=0.98\right)$ and grain $\mathrm{K}$ and $\mathrm{Zn}\left(r^{2}=0.88\right)$; (iii) no correlation between grain $\mathrm{N}$ and $\mathrm{Cu}$ $\left(r^{2}=0.18\right)$ and grain $\mathrm{K}$ and $\mathrm{Cu}\left(r^{2}=0.06\right)$; (iv) a strong correlation between grain $\mathrm{P}$ and $\mathrm{Zn}\left(r^{2}=0.97\right)$ and less so between grain $\mathrm{P}$ and $\mathrm{B}\left(r^{2}=0.69\right)$, while there was no relationship between grain $\mathrm{P}$ and $\mathrm{Cu}\left(r^{2}=0.03\right)$; and (v) a strong correlation between $\mathrm{Zn}$ and grain yield $\left(r^{2}=0.99\right)$ or $\mathrm{B}$ and grain yield $\left(r^{2}=0.89\right)$, but a poor correlation between $\mathrm{Cu}$ and grain yield $\left(r^{2}=0.03\right)$. Based on the treatment effects on grain yield and NPK dynamics, correlating yield or NPK grain levels with those of $\mathrm{B}, \mathrm{Zn}$, or $\mathrm{Cu}$ from the formulations provided an indication of the relative role of each of these micronutrients in this study. Thus, because shoot $\mathrm{Zn}$ and B uptake correlated with yield at physiological maturity and because grain $\mathrm{B}$ and $\mathrm{Zn}$ levels also correlated with grain $\mathrm{N}, \mathrm{P}$, and $\mathrm{K}$, there is a strong indication that $\mathrm{Zn}$ and $\mathrm{B}$, rather than $\mathrm{Cu}$, were the major drivers of yield enhancement under our 
condition and that an application of B or $\mathrm{Zn}$ to plants in dry soils could result in high B or Zn levels, a correspondingly high NPK in the grain, and ultimately in high grain yield. Accordingly, the involvement of $\mathrm{Zn}$ and $\mathrm{B}$ in the plant responses is in agreement with their relative levels, compared to $\mathrm{Cu}$, in the test soil.

Micronutrient effects on plants have previously been compared along the lines of soil vs. foliar application or salts vs. particles. Without going into individual details, these studies show a lack of consistency in crop responses, as reviewed in Dimkpa and Bindraban (2016). However, a meta-analysis by Joy et al. (2015) suggests that foliar treatment with $\mathrm{Zn}$ is more efficient than soil treatment in enhancing $\mathrm{Zn}$ concentrations of crops. In this work, the observed effects varied considerably between the different nutrient delivery methods under drought: the soil-applied salt more efficiently promoted K, $\mathrm{S}, \mathrm{B}, \mathrm{Mn}$ (all in shoot), and $\mathrm{Mg}$ and $\mathrm{S}$ (both in grain) than the foliar-salt, but the opposite was true for $\mathrm{Zn}$ (shoot) and $\mathrm{Cu}$ (shoot and grain). These differences in uptake among the nutrients, including those showing that the proportion of $\mathrm{Zn}$ and $\mathrm{Cu}$ translocated to the grain from soil was greater than from foliar application, with the opposite observation for B, add to the ongoing discussion about the different effectiveness of micronutrient delivery to plants as soil vs. foliar (Joy et al. 2015; Dimkpa and Bindraban 2016). Nevertheless, ultimately, the loss in grain yield (g dry weight) under drought was at full maturity mitigated to the same degree by these treatments: by $36.8 \%$ in the soil-salt treatment and by $37.4 \%$ in the foliar-salt.

Similarly, different crop responses are reported between salt and micnobit-type (nano and/or bulk particles) micronutrients, with many indicators of superior performance by the later, dependent on specific nutrient and crop (Liu and Lal 2015; Dimkpa and Bindraban 2016 and references therein). Such findings have formed the basis for the concept of nanofertilizers. In the present study, however, the degree of stimulation of grain production under drought was not different between the salt and micnobits: 37.4 and $37.2 \%$, respectively. But compared to the foliar salt, the micnobits were slightly more effective in stimulating leaf development and promoted accumulation of $\mathrm{Mn}$ (shoot and grain), $\mathrm{S}, \mathrm{Ca}$, and $\mathrm{Mg}$ (all in grain) than the foliar salt, while the reverse was the case for shoot and grain $\mathrm{Zn}$ and $\mathrm{Cu}$ accumulation. Although the overall difference between salts and micnobits in the current study was not so dramatic, the micnobits showed some promise that warrants further investigation. Clearly, nanofertilizer development, which is the basis for the micnobit treatment, is still a budding one that deserves continued investigation, using environmentally relevant doses, and applied in soil and foliage. Studies are currently underway to understand the effectiveness of micronutrient micnobits as soil-applied nanofertilizers, which is important for their sustainable use, given the fact that their bioactivity can be modulated by different soil types (Watson et al. 2015). While previous studies have demonstrated the impact of drought on soybean (see for, e.g., Samarah et al. 2004), to the best of our knowledge, not only is the present study the first to evaluate boron oxide nanoparticles in crops, no prior studies have demonstrated mitigation of drought stress in soybean using composite micronutrients, most certainly for nanoparticulate nutrients.

\section{Conclusion}

Studies on the mitigation of drought stress in soybean are lacking. Thus, we demonstrate in this study a novel use of composite nanoparticles of micronutrients or their ionic equivalents in the context of fertilizers to boost soybean performance under drought. Both nanoparticle and ionic micronutrient formulations similarly influenced crop growth, yield, and grain micronutrient quality under drought, supporting numerous findings that ion release from the nanoparticles drives their reactivity. Our findings have implications for both quantitative and qualitative human as well as animal nutrition. Considering that human micronutrient deficiency, especially of $\mathrm{Zn}$, is a global problem of topical importance, a micronutrient agronomic fortification strategy that significantly (23\%) increases grain $\mathrm{Zn}$ concentration in an important food crop such as soybean would contribute immensely in fighting hidden hunger. Furthermore, the increased uptake into the plant of $\mathrm{N}$ and $\mathrm{K}$ evoked by the formulations represents evidence for enhanced macronutrient use efficiency. This has potential environmental ramifications especially as it concerns the roles of $\mathrm{N}$ in GHG emission and eutrophication. Nevertheless, more studies are required to correlate $\mathrm{N}$ application rates, $\mathrm{N}$ uptake by plants, residual $\mathrm{N}$ in soil after harvest of micronutrienttreated plants, and measurement of GHGs in the system, in order to draw conclusions on the effectiveness of micronutrients in reducing $\mathrm{N}$ losses and consequent environmental impacts. Collectively, our results demonstrate a micronutrient-based climate-smart intervention with multifaceted benefits-alleviating food insecurity, optimizing resource use, and contributing to resolving hidden hunger.

Acknowledgements Funding for this work was provided in part by the US Agency for International Development (USAID) and the US Department of Agriculture (USDA). We would like to thank Ron Smith, Vaughn Henry, and Joshua Andrews for assistance with plant growth and data collection, as well as Ms. Susan Yiapan for assistance with manuscript formatting.

\section{References}

Al-Kaisi MM, Elmore RW, Guzman JG, Hanna HM, Hart CE, Helmers MJ, Hodgson EW, Lenssen AW, Mallarino AP, Robertson AE, Sawyer JE (2013) Drought impact on crop production and the soil 
environment: 2012 experiences from Iowa. J Soil Water Conserv 68: 1. doi:10.2489/jswc.68.1.19A

Ashraf MY, Iqbal N, Ashraf M, Akhter J (2014) Modulation of physiological and biochemical metabolites in salt stressed rice by foliar application of zinc. J Plant Nutr 37:447-457. doi:10.1080 /01904167.2013.864309

Bagci SA, Ekiz H, Yilmaz A, Cakmak I (2007) Effects of zinc deficiency and drought on grain yield of field-grown wheat cultivars in Central Anatolia. J Agron Crop Sci 193:198-206. doi:10.1111/j.1439-037 X.2007.00256.x

Baligar VC, Fageria NK, He ZL (2001) Nutrient use efficiency in plants. Commun Soil Sci Plant Anal 32:921-950. doi:10.1081/CSS100104098

Barik KC, Chandel AS (2006) Effect of copper levels on copper content in soil nutrient uptake and yield of soybean (Glycine max) varieties. Legume Res 29:252-256

Bouain N, Shahzad Z, Rouached A, Abbas-Khan GA, Berthomieu P, Abdelly C, Poirier Y, Rouached H (2014) Phosphate and zinc transport and signalling in plants, toward a better understanding of their homeostasis interaction. J Exp Bot 65:5725-5741. doi:10.1093 /jxb/eru314

Dimkpa CO, Bindraban PS (2016) Micronutrients fortification for efficient agronomic production. A review. Agron Sustain Dev 36:1-26. doi:10.1007/s13593-015-0346-6

Dimkpa CO, McLean JE, Britt DW, Anderson AJ (2015) Nano-CuO and interaction with nano- $\mathrm{ZnO}$ or soil bacterium provide evidence for the interference of nanoparticles in metal nutrition of plants. Ecotoxicol 24:119-129. doi:10.1007/s10646-014-1364-x

Dimkpa CO, Latta DE, McLean JE, Britt DW, Boyanov MI, Anderson AJ (2013) Fate of $\mathrm{CuO}$ and $\mathrm{ZnO}$ nano and micro particles in the plant. Environ Sci Technol 47:4734-4742. doi:10.1021/es304736y

Dominguez BM, Gomez MVI, Leon FR (2002) Nutritional and analytical implications of phytic acid. Archivos Latino Americanos de Nutri 52:219-231

Eisa GSA, Ali TB (2014) Impact spraying of some microelements on growth, yield, nitrogenase activity and anatomical features of cowpea plants. World J Agric Sci 10:57-67. doi:10.5829/idosi. wjas.2014.10.2.1807

Enderson JT, Mallarino AR, Haq MU (2015) Soybean yield response to foliar-applied micronutrients and relationships among soil and tissue tests. Agron J 107:2143-2161. doi:10.2134/agronj14.0536

Han X, Li X, Uren N, Tang C (2011) Zinc fractions and availability to soybeans in representative soils of Northeast China. J Soils Sed 11: 596-606. doi:10.1007/s11368-011-0336-5

Heitholt JJ, Sloan JJ, MacKown CT (2002) Copper, manganese, and zinc fertilization effects on growth of soybean on a calcareous soil. J Plant Nutr 25:1727-1740. doi:10.1081/PLN-120006054

Hong J, Peralta-Videa JR, Rico C, Shivendra S, Viveros MN, Bartonjo J, Zhao L, Gardea-Torresdey JL (2014) Evidence of translocation and physiological impacts of foliar applied $\mathrm{CeO}_{2}$ nanoparticles on cucumber (Cucumis sativus) plants. Environ Sci Technol 48:43764385. doi:10.1021/es404931g

Inocêncio MF, de Resende ÁV, Neto AEF, Veloso MP, Ferraz FM, Hickmann C (2012) Soybean response to zinc fertilization in soil with contents above critical level. Pesq Agrop Brasileira 47:1550-1554

Joy EJM, Stein AJ, Young SD, Ander EL, Watts MJ, Broadley MR (2015) Zinc-enriched fertilisers as a potential public health intervention in Africa. Plant Soil 389:1-24. doi:10.1007/s11104-015-2430-8

Karim MR, Rahman MA (2015) Drought risk management for increased cereal production in Asian least developed countries. Weath Clim Extr 7:24-35. doi:10.1016/j.wace.2014.10.004
Konsaeng S, Dell B, Rerkasem B (2010) Boron mobility in peanut (Arachis hypogaea L.). Plant Soil 330:281-289. doi:10.1007 /s11104-009-0199-3

Liu R, Lal R (2015) Potentials of engineered nanoparticles as fertilizers for increasing agronomic productions. Sci Total Environ 514:131139. doi:10.1016/j.scitotenv.2015.01.104

Lv J, Zhang S, Luo L, Zhang J, Yang K, Christie P (2014) Accumulation, speciation, and uptake pathway of $\mathrm{ZnO}$ nanoparticles in maize. Environ Sci: Nano 2:68-77. doi:10.1039/C4EN00064A

Manzoor A, Khattak RA, Dost M (2014) Humic acid and micronutrient effects on wheat yield and nutrients uptake in salt affected soils. Int J Agric Biol 16:991-995

Masclaux-Daubresse C, Daniel-Vedele F, Dechorgnat J, Chardon F, Gaufichon L, Suzuki A (2010) Nitrogen uptake, assimilation and remobilization in plants, challenges for sustainable and productive agriculture. Ann Bot 105:1141-1157. doi:10.1093/aob/mcq028

Miwa K, Fujiwara T (2010) Boron transport in plants: co-ordinated regulation of transporters. Ann Bot 105:1103-1108. doi:10.1093 /aob/mcq044

Monreal CM, DeRosa M, Mallubhotla SC, Bindraban PS, Dimkpa CO (2016) Nanotechnologies for increasing the crop use efficiency of fertilizer-micronutrients. Biol Fert Soils 52:423-437. doi:10.1007 /s00374-015-1073-5

Nadeem M, Mollier A, Morel C, Vives A, Prud'homme L, Pellerin S (2011) Relative contribution of seed phosphorus reserves and exogenous phosphorus uptake to maize (Zea mays L.) nutrition during early growth stages. Plant Soil 346:-244. doi:10.1007/s11104-0110814-y

Osakabe Y, Osakabe K, Shinozaki K, Tran LS (2014) Response of plants to water stress. Front Plant Sci 5:86. doi:10.3389/fpls.2014.00086

Pardo EM, Vellicce GR, Aguirrezaba L, Pereyra Irujo G, Rocha CML, García MG, Prieto Angueira S, Welin B, Sanchez J, Ledesma F, Castagnaro AP (2015) Drought tolerance screening under controlled conditions predicts ranking of water-limited yield of field-grown soybean genotypes. J Agron Crop Sci 201:95-104. doi:10.1111 /jac. 12106

Raboy V, Dickinson DB (1984) Effect of phosphorus and zinc nutrition on soybean seed phytic acid and zinc. Plant Physiol 75:1094-1098

Reinbott TM, Blevins DG (1995) Response of soybean to foliar-applied boron and magnesium and soil-applied boron. J Plant Nutr 18:179200. doi:10.1080/01904169509364894

Ross JR, Slaton NA, Brye KR, DeLong RE (2006) Boron fertilization influences on soybean yield and leaf and seed boron concentrations. Agron J 98:198-205. doi:10.2134/agronj2005-0131

Samarah N, Mullen R, Cianzio S (2004) Size distribution and mineral nutrients of soybean seeds in response to drought stress. J Plant Nutri 27:815-835. doi:10.1081/PLN-120030673

Scheiner JD, Gutierrez-Boem FH, Lavado RS (2000) Dynamics of the absorption and division of nutrients in soybean. Phyton-Internat $\mathrm{J}$ Exp Bot 69:77-84

Watson J-L, Fang T, Dimkpa CO, Britt DW, McLean JE, Jacobson A, Anderson AJ (2015) The phytotoxicity of $\mathrm{ZnO}$ nanoparticles on wheat varies with soil properties. Biometals 28:101-112. doi:10.1007/s10534-014-9806-8

Watts-Williams SJ, Turney TW, Patti AF, Cavagnaro TR (2014) Uptake of zinc and phosphorus by plants is affected by zinc fertiliser material and arbuscular mycorrhizas. Plant Soil 376:165-175. doi:10.1007/s11104-013-1967-7

Yruela I (2009) Copper in plants: acquisition, transport and interactions. Funct Plant Biol 26:409-430. doi:10.1071/FP08288 